\title{
Effect of Soil Test Crop Response Basis Integrated Nitrogen Management on Growth and Yield of Wheat (Triticum aestivum L.)
}

\author{
Manish Kakraliya ${ }^{1}$ and Rajesh Singh $^{2 *}$ \\ Department of Agronomy, Sam Higginbottom University of Agriculture, Technology and \\ Sciences, Allahabad, India \\ *Corresponding author
}

A B S T R A C T

\section{Keywords}

Wheat, Integrated nitrogen management, Level of nitrogen, Growth and Yield

\section{Article Info}

Accepted:

30 April 2018

Available Online:

10 June 2018
A field experiment was conducted during the rabi season of 2017 in wheat crop (var. HUW-234) at Crop Research Farm, Department of Agronomy, Naini Agricultural Institute, SHUATS, Allahabad (U.P.). The experiment was laid out in a Randomized Block Design with 12 treatment combinations, consisting of three nitrogen levels $(100,125$ and $150 \mathrm{~kg} \mathrm{~N} / \mathrm{ha}$ ) on soil test basis (STB) compared to farmer practice (FP) and nitrogen management viz. $100 \% \mathrm{~N}$ through urea, $75 \% \mathrm{~N}$ through urea $+25 \% \mathrm{~N}$ through vermicompost with seed inoculation by Azotobacter. The experimental result reveals this saving of nitrogen by 16.5 to $31.7 \mathrm{~kg} / \mathrm{ha}$ without any significant effect on growth and yield of wheat was noticed. The growth parameters viz. plant height, no. of tillers/running row meter, Crop-growth rate (CGR), and Yield attributes viz. No. of effective tillers $/ \mathrm{m}^{2}$, grains/spike and grain yield (4.57 t/ha) were significantly higher with $150 \mathrm{~kg} \mathrm{~N} / \mathrm{ha}$ (Farmer Practice) when applied $100 \% \mathrm{~N}$ through urea, where as plant dry weight, leaf area index (LAI) and straw yield (7.63 t/ha) were significantly higher with $150 \mathrm{~kg}$ N/ha (Farmer Practice) when applied $75 \% \mathrm{~N}$ through urea $+25 \% \mathrm{~N}$ through vermicompost + Azotobacter (Seed inoculation).

\section{Introduction}

Wheat (Triticum aestivum L.) is the most important staple food of about $36 \%$ of the world population and improvement in its productivity has played a key role in making the country self-sufficient in food grains. Worldwide this crop provides nearly 55\% of the carbohydrates and $20 \%$ of the food calories. USDA, 2017 report shows that it is grown in all the continents of the world covering an area of 225.07 million hectares with production of 736.98 million tonnes. In India, total area under wheat is 31.72 million hectares with the production and productivity of 96.0 million tonnes and 3.13 tonnes hectares, respectively (Tiwari et al., 2017).

Nitrogen is subjected to different kinds of losses like denitrification, volatilization and leaching which causes environmental threats. Nitrous oxide has contributed 310 times to the global warming potential of carbon dioxide, and its emissions are affected by poor nitrogen 
management in intensive crop production which is major source for it (Jat et al., 2014). Therefore, the continuous availability of $\mathrm{N}$ to wheat during various phases of its growth and development is important factors which influence the grain quality and yield of wheat. The basic concept underlying the principles of integrated nutrient management (INM) is the maintenance and possibly improvement of soil fertility for sustaining crop productivity on long term basis. This may be achieved through combined use of all possible sources of nutrients and their scientific management for optimum growth, yield and quality of different crops and cropping systems (Patel et al., 2017). Nambiar and Abrol (1989) and Gupta et al., (2000) also reported that under continuous and high intensive farming, the nutrient supplying power of most of the soils has been found to be decline particularly when rice based cropping systems are followed. Due to decline in soil fertility, farmers have to use more and more fertilizer year after year to obtain optimum yield (Hobbs et al., 1990). The excessive and imbalance use of inorganic fertilizer was reported to be the major constraint of declining productivity of ricewheat cropping system (Hobbs, 1994). When these crops are grown under good management conditions, they remove large quantities of nutrients.

However, insufficient $\mathrm{N}$ availability to wheat plants results in low yields and significantly reduced profits compared to a properly fertilized crop. Efficient nutrient-management programmes supply plant nutrients in adequate quantities to sustain maximum crop productivity and profitability while minimizing environmental impacts of nutrient use (Jat et al., 2013). Ensuring optimum nutrient availability through effective nutrientmanagement practices requires knowledge of the interactions between the soil, plant and environment. In this experiment use of some tools for in season nitrogen management like
Site-specific nutrient management (SSNM) through soil-test crop response (STCR) in fulfilling the crop nutrient requirement with less environmental footprints (Jat et al., 2014; Kumar et al., 2014) was planned to see the effect of integrated nitrogen management on soil test basis on growth and yield of wheat.

\section{Materials and Methods}

A experiment was conducted during the Rabi season of 2017 in wheat crop at Crop Research Farm, Department of Agronomy, Naini Agricultural Institute, SHUATS, Allahabad (U.P.). The experiment consisted of three nitrogen levels, viz. 100, 125 and $150 \mathrm{~kg}$ $\mathrm{N} /$ ha through nitrogen management by $100 \%$ $\mathrm{N}$ through urea and $75 \% \mathrm{~N}$ through urea + $25 \% \mathrm{~N}$ through vermicompost with seed inoculation by Azotobacter, laid out in a Randomized Block Design with twelve treatment combinations which replicated thrice. The soil of the experimental field was sandy loam in texture with $\mathrm{pH} 7.6$, low in organic carbon $0.42 \%$, available $\mathrm{P} 13.50 \mathrm{~kg} / \mathrm{ha}$ and available K $257.04 \mathrm{~kg} / \mathrm{ha}$. Wheat 'HUW 234' variety was sown $23^{\text {rd }}$ of November in 2017.

Nitrogen, Phosphorus and Potassium were applied through urea, single super phosphate and muriate of potash, respectively. Half of nitrogen as per treatment and full dose of phosphorus, potassium and remaining nitrogen as per treatment was top dressed after the soil test analysis.. The crop received five uniform irrigations. All the growth and yield attributes were recorded using standard procedure and grain yield was calculated at $12 \%$ moisture content.

The crop growth rate (CGR) was calculated using the standard procedure and formulae. The leaf-area index (LAI) was calculated by dividing leaf area with ground area available for each plant. 


\section{Results and Discussion}

Effect on growth attributes and growth rates

Among N-management practices in wheat, application of $150 \mathrm{~kg} \mathrm{~N} / \mathrm{ha}$ (Farmer Practice) $100 \% \mathrm{~N}$ through urea produced significantly higher growth attributing characters, i.e. plant height $(72.99 \mathrm{~cm})$, No. of tillers/running row meter (82.67) and CGR (2.775 g/m²/day) at 40-60 DAS. The results of the present investigation are in close conformity with those of Singh et al., (2007) and Singh et al., (2013).

The dry-matter accumulation $(23.10 \mathrm{~g})$ and leaf area index (4.18) when found to be significantly higher with $150 \mathrm{~kg} \mathrm{~N} / \mathrm{ha}$ (Farmer Practice) $75 \% \mathrm{~N}$ through urea $+25 \% \mathrm{~N}$ through vermicompost + Azotobacter (Seed inoculation). It may be attributed to higher availability of nutrients in vermicompost, increased availability of both the native and applied nutrients and better source and sink relationship that contributed to better drymatter production of crops leading to the production of favourable yield components.

Kumawat et al., (2006) and Khandwel et al., (2006) have also reported better response of integrated nutrient management by crops. Integrated nitrogen management leads to higher leaf-area index (LAI), leading to higher photosynthetic rate and accumulation of more assimilates which in turn increased the sink size. Similar findings were reported to by Verma et al., (2016).

\section{Effect on yields and yield attributes}

Effective number of tillers (320.00), number of grains/spike (58.00) significantly higher with $150 \mathrm{~kg} \mathrm{~N} / \mathrm{ha}$ (Farmer Practice) $100 \% \mathrm{~N}$ through urea.
The results are in close agreement with the findings of Singh et al., (2011) and Prajapat et $a l$. , (2014). The length of spike $(11.53 \mathrm{~cm})$ was significantly higher with $125 \mathrm{~kg} \mathrm{~N} / \mathrm{ha}$ (Farmer Practice) 100\% through urea. Similar findings were also reported by Gupta et al., (2007).

The grain yield (4.57 t/ha) and harvest index $(44.31 \%)$ was also higher with $150 \mathrm{~kg} \mathrm{~N} / \mathrm{ha}$ (Farmer Practice) $100 \% \mathrm{~N}$ through urea that may be due to cumulative effect of growth and yield-attributing characters owing to fertilization. Greater availability of metabolites (photosynthates) and nutrients to developing reproductive structures seems to have resulted in increase in all the yieldattributing characters which ultimately improved the yield of the crop. Similar findings were also reported by Singh et al., (2010), Tripathi et al., (2013) and Pandey et al., (2006).

The straw yield (7.63 t/ha) was higher with $150 \mathrm{~kg} \mathrm{~N} / \mathrm{ha}$ (Farmer Practice) 75\% N through urea $+25 \% \mathrm{~N}$ through vermicompost + Azotobacter (Seed inoculation). The integrated use of organic and inorganic source of nutrients might have supplied readily available nutrients to crop which resulted in greater assimilation, production and partitioning of dry- matter to yield. Similar findings also reported were found by Verma et al., (2016) and Singh et al., (2016).

On the basis of above findings it can be concluded that for obtaining higher grain yield, number of effective tillers $/ \mathrm{m}^{2}$ and other growth and yield attributes were found to be the best treatment $150 \mathrm{~kg} \mathrm{~N} / \mathrm{ha}$ (Farmer Practice) when applied $100 \% \mathrm{~N}$ through Urea with wheat variety HUW-234 (Malviya). These findings are based on 1 season; therefore, further trials may be required for considering it for recommendation. 
Table.1 Effect of soil test crop response basis integrated nitrogen management on growth attributes in wheat

\begin{tabular}{|c|c|c|c|c|c|c|}
\hline & \multirow[t]{2}{*}{ Treatments } & \multicolumn{4}{|c|}{ Growth attributes (80 DAS) } & \multirow{2}{*}{$\begin{array}{c}\text { Growth Rate } \\
\text { (40-60 DAS) } \\
\text { Crop Growth } \\
\text { Rate } \\
\left(\mathrm{g} / \mathrm{m}^{2} / \mathrm{day}\right)\end{array}$} \\
\hline & & $\begin{array}{c}\text { Plant } \\
\text { height } \\
(\mathbf{c m})\end{array}$ & $\begin{array}{c}\text { No. of tillers } \\
\text { (Running row } \\
\text { meter) }\end{array}$ & $\begin{array}{l}\text { Plant } \\
\text { Dry weight } \\
\text { (g) }\end{array}$ & $\begin{array}{l}\text { Leaf area } \\
\text { index } \\
\text { (LAI) }\end{array}$ & \\
\hline $\mathbf{T}_{\mathbf{1}}$ & {$[100 \mathrm{~kg} \mathrm{~N} / \mathrm{ha}(\mathrm{STB})] 100 \% \mathrm{~N}$ through Urea } & 47.27 & 65.00 & 10.92 & 2.79 & 1.114 \\
\hline $\mathbf{T}_{2}$ & {$[100 \mathrm{~kg} \mathrm{~N} / \mathrm{ha}(\mathrm{STB})] 75 \% \mathrm{~N}$ through Urea $+25 \% \mathrm{~N}$ through $\mathrm{VC}+$ Azotobacter $(\mathrm{SI})$} & 48.09 & 70.33 & 17.03 & 3.37 & 2.107 \\
\hline $\mathbf{T}_{\mathbf{3}}$ & [125 kg N/ha (STB)] 100\% N through Urea & 49.95 & 68.00 & 14.10 & 3.50 & 1.483 \\
\hline $\mathbf{T}_{4}$ & {$[125 \mathrm{~kg} \mathrm{~N} / \mathrm{ha}(\mathrm{STB})] 75 \% \mathrm{~N}$ through Urea $+25 \% \mathrm{~N}$ through VC + Azotobacter $(\mathrm{SI})$} & 51.17 & 72.67 & 16.83 & 3.74 & 1.913 \\
\hline $\mathbf{T}_{\mathbf{5}}$ & {$[150 \mathrm{~kg} \mathrm{~N} / \mathrm{ha}(\mathrm{STB})] 100 \% \mathrm{~N}$ through Urea } & 52.24 & 78.33 & 21.13 & 3.98 & 2.463 \\
\hline $\mathbf{T}_{6}$ & {$[150 \mathrm{~kg} \mathrm{~N} / \mathrm{ha}(\mathrm{STB})] 75 \% \mathrm{~N}$ through Urea $+25 \% \mathrm{~N}$ through $\mathrm{VC}+$ Azotobacter $(\mathrm{SI})$} & 52.91 & 79.00 & 22.30 & 4.04 & 2.653 \\
\hline $\mathbf{T}_{7}$ & {$[100 \mathrm{~kg} \mathrm{~N} / \mathrm{ha}(\mathrm{FP})] 100 \% \mathrm{~N}$ through Urea } & 49.34 & 67.33 & 12.88 & 3.15 & 1.329 \\
\hline $\mathbf{T}_{8}$ & {$[100 \mathrm{~kg} \mathrm{~N} / \mathrm{ha}(\mathrm{FP})] 75 \% \mathrm{~N}$ through Urea $+25 \% \mathrm{~N}$ through VC + Azotobacter $(\mathrm{SI})$} & 50.07 & 69.00 & 12.84 & 3.27 & 1.172 \\
\hline $\mathbf{T}_{9}$ & {$[125 \mathrm{~kg} \mathrm{~N} / \mathrm{ha}(\mathrm{FP})] 100 \% \mathrm{~N}$ through Urea } & 50.66 & 72.33 & 19.53 & 3.16 & 2.046 \\
\hline $\mathbf{T}_{10}$ & {$[125 \mathrm{~kg} \mathrm{~N} / \mathrm{ha}(\mathrm{FP})] 75 \% \mathrm{~N}$ through Urea $+25 \% \mathrm{~N}$ through VC + Azotobacter $(\mathrm{SI})$} & 51.33 & 74.67 & 17.12 & 3.34 & 1.534 \\
\hline $\mathbf{T}_{11}$ & {$[150 \mathrm{~kg} \mathrm{~N} / \mathrm{ha}(\mathrm{FP})] 100 \% \mathrm{~N}$ through Urea } & 54.21 & 82.67 & 23.10 & 4.14 & 2.775 \\
\hline \multirow[t]{3}{*}{$\mathbf{T}_{12}$} & {$[150 \mathrm{~kg} \mathrm{~N} / \mathrm{ha}(\mathrm{FP})] 75 \% \mathrm{~N}$ through Urea $+25 \% \mathrm{~N}$ through VC + Azotobacter $(\mathrm{SI})$} & 53.62 & 81.67 & 22.24 & 4.18 & 2.535 \\
\hline & SEd $( \pm)$ & 0.72 & 2.14 & 2.69 & 0.37 & 0.342 \\
\hline & $\mathrm{CD}(\mathrm{P}=0.05)$ & 1.50 & 4.43 & 5.58 & 0.78 & 0.710 \\
\hline
\end{tabular}

*STB- Soil test basis; FP- Farmer Practice; VC-Vermicompost; SI- Seed inoculation 
Table.2 Effect of soil test crop response basis integrated nitrogen management on yield attributes in wheat

\begin{tabular}{|c|c|c|c|c|c|}
\hline & \multirow[t]{2}{*}{ Treatments } & \multicolumn{4}{|c|}{ Yield attributes } \\
\hline & & $\begin{array}{c}\text { Number of } \\
\text { effective tillers/ } \\
\mathbf{m}^{2}\end{array}$ & $\begin{array}{l}\text { Length of } \\
\text { spike }(\mathrm{cm})\end{array}$ & $\begin{array}{l}\text { No. of grains/ } \\
\text { spike }\end{array}$ & $\begin{array}{c}\text { Test weight } \\
\text { (g) }\end{array}$ \\
\hline $\mathbf{T}_{1}$ & {$[100 \mathrm{~kg} \mathrm{~N} / \mathrm{ha}(\mathrm{STB})] 100 \% \mathrm{~N}$ through Urea } & 250.67 & 8.90 & 46.67 & 39.61 \\
\hline $\mathbf{T}_{2}$ & {$[100 \mathrm{~kg} \mathrm{~N} / \mathrm{ha}(\mathrm{STB})] 75 \% \mathrm{~N}$ through Urea $+25 \% \mathrm{~N}$ through $\mathrm{VC}+$ Azotobacter $(\mathrm{SI})$} & 264.00 & 10.00 & 51.33 & 39.89 \\
\hline $\mathbf{T}_{3}$ & [125 kg N/ha (STB)] 100\% N through Urea & 265.33 & 9.73 & 50.00 & 39.44 \\
\hline $\mathbf{T}_{4}$ & {$[125 \mathrm{~kg} \mathrm{~N} / \mathrm{ha}(\mathrm{STB})] 75 \% \mathrm{~N}$ through Urea $+25 \% \mathrm{~N}$ through $\mathrm{VC}+$ Azotobacter $(\mathrm{SI})$} & 284.00 & 10.50 & 50.33 & 40.46 \\
\hline $\mathbf{T}_{5}$ & [150 kg N/ha(STB)] 100\% N through Urea & 302.67 & 10.70 & 54.67 & 42.35 \\
\hline $\mathbf{T}_{6}$ & {$[150 \mathrm{~kg} \mathrm{~N} / \mathrm{ha}(\mathrm{STB})] 75 \% \mathrm{~N}$ through Urea $+25 \% \mathrm{~N}$ through VC + Azotobacter (SI) } & 306.67 & 11.23 & 57.33 & 41.78 \\
\hline $\mathbf{T}_{7}$ & {$[100 \mathrm{~kg} \mathrm{~N} / \mathrm{ha}(\mathrm{FP})] 100 \% \mathrm{~N}$ through Urea } & 261.33 & 9.57 & 50.00 & 39.47 \\
\hline $\mathbf{T}_{8}$ & {$[100 \mathrm{~kg} \mathrm{~N} / \mathrm{ha}(\mathrm{FP})] 75 \% \mathrm{~N}$ through Urea $+25 \% \mathrm{~N}$ through $\mathrm{VC}+$ Azotobacter $(\mathrm{SI})$} & 269.33 & 9.70 & 51.33 & 39.46 \\
\hline $\mathbf{T}_{9}$ & [125 kg N/ha (FP)] 100\% N through Urea & 280.00 & 11.53 & 54.67 & 40.40 \\
\hline $\mathbf{T}_{10}$ & {$[125 \mathrm{~kg} \mathrm{~N} / \mathrm{ha}(\mathrm{FP})] 75 \% \mathrm{~N}$ through Urea $+25 \% \mathrm{~N}$ through $\mathrm{VC}+$ Azotobacter $(\mathrm{SI})$} & 285.33 & 10.33 & 55.00 & 40.63 \\
\hline $\mathbf{T}_{11}$ & {$[150 \mathrm{~kg} \mathrm{~N} / \mathrm{ha}(\mathrm{FP})] 100 \% \mathrm{~N}$ through Urea } & 320.00 & 11.50 & 58.00 & 41.61 \\
\hline $\mathbf{T}_{12}$ & {$[150 \mathrm{~kg} \mathrm{~N} / \mathrm{ha}(\mathrm{FP})] 75 \% \mathrm{~N}$ through Urea $+25 \% \mathrm{~N}$ through $\mathrm{VC}+$ Azotobacter $(\mathrm{SI})$} & 318.67 & 11.43 & 57.67 & 42.12 \\
\hline & SEd $( \pm)$ & 6.61 & 0.53 & 2.01 & 0.75 \\
\hline & $\mathrm{CD}(\mathrm{P}=0.05)$ & 13.71 & 1.10 & 4.16 & 1.55 \\
\hline
\end{tabular}


Table.3 Effect of soil test crop response basis integrated nitrogen management on yield and harvest index in wheat

\begin{tabular}{|c|c|c|c|c|}
\hline & \multirow[t]{2}{*}{ Treatments } & \multicolumn{3}{|c|}{ Yield and Harvest Index } \\
\hline & & $\begin{array}{l}\text { Grain yield } \\
\text { (t/ha) }\end{array}$ & $\begin{array}{c}\text { Straw yield } \\
\text { (t/ha) }\end{array}$ & $\begin{array}{c}\text { Harvest Index } \\
(\%)\end{array}$ \\
\hline $\mathbf{T}_{1}$ & [100 kg N/ha (STB)] 100\% N through Urea & 2.70 & 5.03 & 35.16 \\
\hline $\mathbf{T}_{2}$ & {$[100 \mathrm{~kg} \mathrm{~N} / \mathrm{ha}(\mathrm{STB})] 75 \% \mathrm{~N}$ through Urea $+25 \% \mathrm{~N}$ through VC + Azotobacter $(\mathrm{SI})$} & 3.18 & 5.77 & 35.58 \\
\hline $\mathbf{T}_{\mathbf{3}}$ & [125 kg N/ha (STB)] 100\% N through Urea & 2.97 & 6.15 & 32.53 \\
\hline $\mathbf{T}_{4}$ & {$[125 \mathrm{~kg} \mathrm{~N} / \mathrm{ha}(\mathrm{STB})] 75 \% \mathrm{~N}$ through Urea $+25 \% \mathrm{~N}$ through $\mathrm{VC}+$ Azotobacter $(\mathrm{SI})$} & 3.97 & 7.02 & 36.11 \\
\hline $\mathbf{T}_{5}$ & {$[150 \mathrm{~kg} \mathrm{~N} / \mathrm{ha}(\mathrm{STB})] 100 \% \mathrm{~N}$ through Urea } & 4.23 & 7.55 & 35.98 \\
\hline $\mathbf{T}_{6}$ & {$[150 \mathrm{~kg} \mathrm{~N} / \mathrm{ha}(\mathrm{STB})] 75 \% \mathrm{~N}$ through Urea $+25 \% \mathrm{~N}$ through $\mathrm{VC}+$ Azotobacter $(\mathrm{SI})$} & 4.27 & 7.57 & 36.08 \\
\hline $\mathbf{T}_{7}$ & {$[100 \mathrm{~kg} \mathrm{~N} / \mathrm{ha}(\mathrm{FP})] 100 \% \mathrm{~N}$ through Urea } & 3.43 & 5.10 & 40.21 \\
\hline $\mathbf{T}_{\mathbf{8}}$ & {$[100 \mathrm{~kg} \mathrm{~N} / \mathrm{ha}(\mathrm{FP})] 75 \% \mathrm{~N}$ through Urea $+25 \% \mathrm{~N}$ through VC + Azotobacter $(\mathrm{SI})$} & 4.20 & 5.73 & 42.61 \\
\hline $\mathbf{T}_{9}$ & {$[125 \mathrm{~kg} \mathrm{~N} / \mathrm{ha}(\mathrm{FP})] 100 \% \mathrm{~N}$ through Urea } & 3.82 & 6.55 & 36.93 \\
\hline $\mathbf{T}_{10}$ & {$[125 \mathrm{~kg} \mathrm{~N} / \mathrm{ha}(\mathrm{FP})] 75 \% \mathrm{~N}$ through Urea $+25 \% \mathrm{~N}$ through $\mathrm{VC}+$ Azotobacter $(\mathrm{SI})$} & 4.27 & 6.50 & 39.62 \\
\hline $\mathbf{T}_{11}$ & {$[150 \mathrm{~kg} \mathrm{~N} / \mathrm{ha}(\mathrm{FP})] 100 \% \mathrm{~N}$ through Urea } & 4.57 & 5.75 & 44.31 \\
\hline $\mathbf{T}_{12}$ & {$[150 \mathrm{~kg} \mathrm{~N} / \mathrm{ha}(\mathrm{FP})] 75 \% \mathrm{~N}$ through Urea $+25 \% \mathrm{~N}$ through $\mathrm{VC}+$ Azotobacter $(\mathrm{SI})$} & 4.50 & 7.63 & 37.03 \\
\hline & SEd $( \pm)$ & 0.30 & 0.62 & 1.99 \\
\hline & $\mathrm{CD}(\mathrm{P}=0.05)$ & 0.62 & 1.28 & 4.12 \\
\hline
\end{tabular}

*STB- Soil test basis; FP- Farmer Practice; VC- Vermicompost; SI- Seed inoculation 


\section{References}

Balwan, Yadav, L.R., Verma, H.P., Kumar, R. and Yadav, S.S. 2017 Effect of fertility levels and antitranspirants on productivity and profitability of wheat (Triticum aestivum) varieties. Indian Journal of Agronomy 62 (1): 45-48.

Barthwal, A., Bhardwaj, A.K., Chaturvedi, S. and Pandiaraj, T. 2013 Site specific NPK recommendation in wheat (Triticum aestivum) for sustained crop and soil productivity in mollisols of Tarai region. Indian Journal of Agronomy 58 (2): 208-214.

Jat, M.L., Satyanarayana, T., Majumdar, Kaushik, Parihar, C.M., Jat, S.L., Tetarwal, J.P., Jat, R.K. and Saharawat, Y.S. 2013. Fertilizer best management practices for maize systems. Indian Journal of Fertilisers 9(4): 80-94.

Mohanty, S.K., Singh, A.K., Jat, S.L., Parihar, C.M., Pooniya, V., Sharma S., Sandhya, Chaudhary, V. and Singh, B. 2015 Precision nitrogen-management practices influences growth and yield of wheat (Triticum aestivum) under conservation agriculture. Indian Journal of Agronomy 60 (4): 617-621.

Narolia, R.S., Meena, H., Singh, P., Meena, B.S. and Baldev Ram. 2016 Effect of irrigation scheduling and nutrient management on productivity, profitability and nutrient uptake of wheat (Triticum aestivum) grown under zero-tilled condition in southeastern Rajasthan. Indian Journal of Agronomy 61 (1): 53-58.

Pandey, I.B., Dwivedi, D.K., and Prakash, S.C. 2006. Impact of method and levels of fertilizer application and weed management on nutrient economy and yield of wheat (Triticum aestivum). Indian Journal of Agronomy 51 (3): 193-198

Patel, T.G., Patel, C. and Patel V. N. 2017. Effect of integrated nutrient management on yield attributes and yield of wheat (Triticum aestivum). International Journal of Chemical Studies. 5 (4): 1366-1369.

Tiwari, A., Rai, O.P., Singh, G., Sharma, J. D., Harikesh and Singh, V. 2017 Studies on effect of nitrogen and weed management on yield and economics of late sown wheat (Triticum aestivum). Journal of Pharmacognosy and Phytochemistry 6 (6): 379-383

Tripathi, S.C., Subhash Chander and Meena, R. P. 2013 Effect of early sowing, N levels and seed rates on yield and yield attributes of different wheat (Triticum aestivum) varieties. Indian Journal of Agronomy 58 (1): 63-66.

Verma, R.K., Shivay, Y.S., Kumar, D. and Ghasal, P.C. 2016 Productivity and profitability of wheat (Triticum aestivum) as influenced by different cropping systems and nutrient sources. Indian Journal of Agronomy 61 (4): 429-435.

\section{How to cite this article:}

Manish Kakraliya and Rajesh Singh. 2018. Effect of Soil Test Crop Response basis Integrated Nitrogen Management on Growth and Yield of Wheat (Triticum aestivum L.). Int.J.Curr.Microbiol.App.Sci. 7(06): 3708-3714. doi: https://doi.org/10.20546/ijcmas.2018.706.434 